IJ§ER

ISSN: $2149-5939$
International Journal of Social Sciences and Education Research

Online, http://dergipark.gov.tr/ijsser

Volume: 1(1), 2015

\title{
Otel animasyon hizmetlerinin yöneticiler ve turistlerin bakış açısıyla değerlendirilmesi ${ }^{1}$
}

The evaluation of hotel animation services from managers and tourists' perspective

\begin{abstract}
Mahmut Demir²
Şirvan Şen Demir 3

Received Date: $01 / 01 / 2015$

Accepted Date: $01 / 02$ / 2015

$\ddot{O} z$

Otel animasyon hizmetleri hem yönetim hem de turistler açısından önemsenmektedir. Kıyı bölgelerindeki resort otellerde rekreasyon ve animasyon hizmetlerinden turistlerin memnuniyeti yiyecek-içecek satışlarının artmasına da katkı sağlayabilmektedir. Bu animasyonlar, spor aktiviteleri, akşam ĕglence/gösterileri ve çocuklar için eğlence programları olmak üzere üç animasyon hizmetlerini içerir. Bu çalıșmanın amacı otel yöneticileri ve turistlerin bakış açısıyla animasyon hizmetlerini değerlendirmektir. Nitel araştırma yöntemi kullanılan bu çalışmada öncelikle otellerde rekreasyon ve animasyon hizmetleriyle ilgili alan yazın taraması gerçekleştirilmiştir. Sonra Antalya ve Muğla Bölgelerindeki otellerde 10 yönetici ve 22 turist ile yüz yüze mülakatlar yapılarak veriler toplanmıştır. Sonuçlar otel yönetici ve turistlerin müşteri memnuniyetinde otel animasyonları ve personelinin önemli bir rolü olduğuna inandıklarını göstermektedir.
\end{abstract}

Anahtar sözcükler: Animasyon hizmetleri, Otel, Yöneticiler, Turistler

\begin{abstract}
Hotel animation services are important for both management and tourists. Tourist satisfaction with recreational and animation services can contribute to increase food and beverage sales during show programs at hotels and resorts in the coastal regions. Animation services include three types of animation programs such as, sports activities, evening entertainment/shows and entertainment programs for children. The purpose of this study is to evaluate hotel animation services from managers and tourist perspective. This paper which qualitative research method was used in, firstly, a literature review that related to recreational and animation services at hotels were conducted and then data were collected by researchers in face-to-face interviews with 10 managers and 22 tourists at hotels and resorts in Antalya and Muğla. The results indicate that managers and tourists believe in hotel animation programs and people have a crucial role on customer satisfaction.
\end{abstract}

Keywords: Animation services, Hotel, Managers, Tourists

\section{Giriş}

Dünya'da endüstri devrimiyle yaşanan değişim ve gelişmelere bağlı olarak çalışma saatlerinin azaltılması ve ücretli tatil hakkı verilmesi sonucunda çalışanların serbest zamanlarının arttığı görülmektedir. Serbest zamanlarını çeşitli rekreatif etkinliklerle doldurma çabası içindeki insanların

\footnotetext{
${ }^{1} \mathrm{Bu}$ çalışma 31 Ekim-3 Kasım 2013 tarihlerinde Kuşadası'nda gerçekleştirilen II. Rekreasyon Araştırmaları Kongresinde sunulan "Otel Animasyon Faaliyetlerinin Yönetici ve Turistlerin Bakış Açısıyla Değerlendirilmesi” isimli bildirinin gözden geçirilmiş ve genişletilmiş halidir.

${ }^{2}$ Sorumlu yazar: Doç. Dr., Süleyman Demirel Üniversitesi, Eğirdir Turizm ve Otelcilik Yüksekokulu, mdemir1@gmail.com.

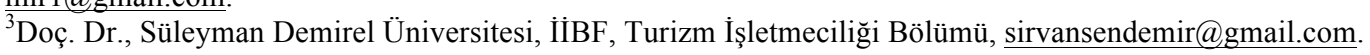


Demir, M. \& Demir, Ş.Ş. (2015). Otel animasyon hizmetlerinin yöneticiler ve turistlerin bakış açısıyla değerlendirilmesi. International Journal of Social Sciences and Education Research, 1 (1), 35-48.

yöneldikleri etkinliklerden birisi de turizmdir. Turizm, genlikle dinlenme, eğlenme amacı taşıyan, serbest zamanları değerlendirme gereksiniminden kaynaklanmaktadır (Borhan \& Erkmen, 2009). Özellikle ikinci dünya savaşından sonra atıl kalan savaş uçaklarının turizm amacı ile kullanılması çok uzak mesafelere insanların daha kısa sürede ulaşabilmelerini sağlamıştır. Daha sonraki teknolojik gelişmelerle birlikte daha büyük uçakların yapılması, daha fazla sayıda insanın bu ulaşım aracından daha ucuza yararlanmasını sağlamıştır. Artık daha fazla sayıda insan çok daha ucuza tatil yapabilmektedir. Özellikle soğuk iklime sahip ülkede yaşayanların sıcak denizlere kolay ulaşması beraberinde kitle turizmini getirmiştir.

Kitle turizminin ortaya çıkardığı deniz/kum/güneş ve kar/kayak odaklı resort oteller misafirlerini tesis içinde daha fazla tutmak amacıyla farklı organizasyonlara yönelmektedir. Bu tür tesislerde turistlerin konaklama dişındaki yeme-içme, alışveriş, spor gibi birçok gereksinimi de aynı alan içerisinde karşılamaya başlamıştır. Ancak otel içerisinde bir kaç gün geçirdikten sonra sıkılmaya başlayan turistlerin eğlenme gereksinimlerini karşılayacak olan animasyon programları ilk kez 1980'li yıllarda İspanya, İtalya ve Yunanistan'da başlamıştır (Glinia, Costa \& Drakou, 2004). Türkiye'de ise, ilk kez Club Med ile başlayan animasyon hizmetinin müşteri memnuniyetine olumlu etki etmesi ile birlikte, 1990'lı yıllarda diğer resort oteller ve tatil köyleri tarafından da uygulanmaya başlanmıştır. Ancak o dönemde Türkiye'de animasyonu gerçekleştirebilecek yeterli personel olmadığı için bu tür eğlence programları yabancı tur operatörlerinin turla birlikte getirdikleri kendi animatörleri tarafından yapılmaktadır (Koçak, 2001). Günümüzde, Türk animatörlerin yetişmesinde oldukça önemli bir yere sahip olan yabancı animatörlerin ilk yıllara göre oranlarının daha düşük olduğu ifade edilebilir.

\section{Otellerde animasyon hizmetleri}

Otel animasyonu canlı eğlence hizmetlerinin yanı sıra, serbest zaman, fitness ve spor faaliyetlerinin de yer aldığ̣ rekreasyon hizmetlerini de içermektedir. Zaten "animate" sözcüğünden gelen animasyon, aktif hale gelme, canlanma, aktif bir yaşam sunma anlamı yanında, canlandırma ve yenileme anlamına gelen "recreating" kelimesini de içermektedir (Glinia, Costa \& Drakou, 2004). Otelde turistlerin zamanlarını en iyi şekilde geçirmelerini sağlama sorumluluğu yüklenen animasyon hizmetleri resort otel ürün kalitesinde oldukça önemli bir rol oynamaktadır (Vogt \& Fesenmeier,1995). Animasyon hizmeti özellikle herşey dahil sistemi uygulayan işletmelerde turistlerin tatil süresince otel içinde daha fazla kalmalarını sağlarken, onları eğlendirerek, canlandırarak, spor yapmalarını sağlayarak keyifli bir tatil geçirmesine katkı sağlamaktadır. Otellerdeki animasyon hizmeti turistlerin diğer turistlerle sosyal ilişkiler kurmalarını kolaylaştırmanın yanı sıra yerel kültür hakkında bilgi edinmelerini de sağlama gibi bir misyonu bulunmaktadır (Shportko, 2012). Ancak animatörlerin yeterli eğitimi almamış olmaları ve yeteri kadar Türk halk kültürü ile ilgili bilgiye sahibi olmamaları nedeniyle çoğu kez gösteriler bu misyonu yerine getirememektedir.

Otel animasyon hizmetleri spor faaliyetleri, gece gösterileri ve çocuk animasyonu (mini kulüp) olarak sınıflandırılabilir (Mikulic \& Prebezac, 2011). Spor faaliyetleri genellikle gündüz saatlerinde yapılan sabah jimnastiği, su topu, plaj voleybolu, dart, bocce gibi basit, grup halinde yap1labilecek oyunları ve yarışmaları kapsamaktadır. Spor faaliyetleri hem turistlerin spor yaparak canlanmalarını, hem de birbirleri ile iletişim kurmalarını sağlamaktır. Spor faaliyetlerini turistlerle birlikte yapacak olan animatörlerin yeterli düzeyde bilgi sahibi olmasının yanı sıra onları 
Demir, M. \& Demir, Ş.Ş. (2015). The evaluation of hotel animation services from managers and tourists' perspective. International Journal of Social Sciences and Education Research, 1 (1), 35-48.

zorlamadan bu oyunlara katılmaları sağlayacak ikna yeteneğine sahip olmaları da oldukça önemlidir. Animatör-turist ilişkisinin diğer insanları rahatsız edecek düzeyde ve şekilde olmaması oldukça önemlidir.

Gece gösterileri, akşam yemeğinden sonraki zamanlarını nasıl değerlendireceğini bilmeyen turistlere yardımcı olmak amacıyla yapılmaktadır. Bu gösteriler skeçler, playback showlar, kabareler, müzikaller, dans gösterileri, çeşitli yarışmalar, değişik ülkelere ait geceleri (Türk gecesi, Latin gecesi gibi) kapsamaktadır. Gösteriler genellikle turistlerin oteldeki kalış süreleri dikkate alınarak belli aralıklarla, örneğin 7 veya 15 günde bir olmak üzere, tekrarlanmaktadır. Gece gösterilerinin gerek kostüm, gerekse dekor bakımından zengin olması, ayrıca herkesçe bilinen basit gösteriler olmaması oldukça önemlidir. Gece gösterilerinde görev alan animatörlerin dans ve tiyatro yeteneklerinin olması yanı sıra müşterilerin milliyetlerine göre birkaç dili konuşabiliyor olması önemlidir. Çünkü animatörler gösteri sırasında söyledikleri cümleleri bir kaç farklı dilde tekrarlamak zorundadir.

Çocuk animasyon hizmeti ise hem çocuklara hem de onların ailelerine hitap etmektedir. Bazı aileler çocuklarına günlük yaşamlarında zaman ayıramadığı için tatilde onlarla birlikte değişik etkinliklerde bulunarak hoş vakit geçirmek isterken bazıları da tatilde kendilerine zaman ayırabilmek için çocukları ile ilgilenecek, onları eğlendirme hizmetini yapabilecek bir yer aramaktadır (Mikulic \& Prebezac, 2011). Çocuk animasyonunda gündüz değişik faaliyetler, yarışmalar yaptırılmakta, onların birbiriyle kaynaşmaları ve oyun oynamaları sağlanmakta, akşam ise, gece gösterisinden önce çocuklar ve isteyen ailelerle birlikte mini club dansları yapılmaktadır. Özellikle bu bölümde çocuk psikolojisinden anlayan, sabırlı, sorumluluk sahibi ve müşteri özelliklerine bağlı olarak farklı yabancı dilleri bilen animatörlerin istihdam edilmesi oldukça önemlidir. Yap1lan araştırmalar çocukların tatil seçiminde ailelerin kararında oldukça önemli bir yere sahip olduğunu göstermektedir (Costa \& Glinia, 2004; Mikulić \& Prebežac, 2011; Pompl, 1983). Müşterilerin tercihleri ve memnuniyetlerinde artış göz önüne alındığında işletmelerin çocuk animasyon hizmetine önem vermeleri gerekliliği ortaya çıkmaktadır.

Özellikle herşey dahil pansiyon türünü uygulayan otellerin animasyon ekipleri ve gösterilerinin kaliteli ve orjinal olması müşteri memnuniyeti açısından oldukça önemlidir (Demir \& Demir, 2001). Günümüzde animasyonun otel tatil paketinin içinde öneminin giderek artmasına rağmen, işletmelerin animasyon birimi ve faaliyetlerine yeterli bütçe ayırmadıkları da bilinmektedir. $\mathrm{Bu}$ durum gösterilerin ve animatörlerin kalitesine, dolayısıyla da müşteri memnuniyetsizliğine yansımaktadır. İşletmeler maliyetleri azaltmak için işe aldıkları animatörlerin deneyim ve yeteneklerini dikkate almamakta, daha önce hiç animatörlük yapmamış, bu konuda herhangi bir eğitim almamış personeli istihdam edebilmekte ya da bir animasyon şirketi ile anlaşarak düşük maliyetli eğlence faaliyetleri ile hizmet verebilmektedir.

Özellikle deniz/kum/güneş odaklı tatillere yönelik hizmet veren büyük ve zincir resort otellerin sayısındaki artış ile birlikte profesyonel animatörlere daha fazla gereksinim olmaktadır (Glinia, Costa \& Drakou, 2004). Ancak sadece Türkiye'de değil, diğer birçok turizm ülkesinde de kalifiye animatör bulmak önemli bir sorundur. Costa ve arkadaşları (2004) Yunanistan'da profesyonel animatör eksikliğinden dolayı bu departmanın hizmet kalitesinin standartların altında kaldığını belirtmektedir. Yapılan bu çalışmada animasyon personelinin eğitiminin son derece yetersiz olduğu belirtilerek, animatörlerin sadece \%57'sinin yüksek öğrenimli, bunlarında büyük çoğunluğunun (\%63) turizm dışındaki okullardan mezun olduğu belirtilmektedir. Animatörlerin 
Demir, M. \& Demir, Ş.Ş. (2015). Otel animasyon hizmetlerinin yöneticiler ve turistlerin bakış açısıyla değerlendirilmesi. International Journal of Social Sciences and Education Research, 1 (1), 35-48.

büyük çoğunluğunun otelin animasyon şefinden aldıkları birkaç haftalık eğitimlerle bu işe başladıkları da bilinen bir gerçektir (Koçak, 2001). Alınan bu eğitimler genellikle sezon içinde yapılacak gösterilere yönelik olmakta ve uzun süreli çalışma programlarını kapsamamaktadır.

Animasyon hizmetlerini gerçekleştirecek personeli işe alırken dikkatli seçim yapılması, kaliteli eğlence hizmeti açısından da oldukça önemlidir. Animatörler birçok beceriyi bir arada bulunduran kişiler olarak algılanmaktadır. İyi bir animatör cömert, neşeli, konuşkan, yaratıcı, ilgili, dürüst, kültürlü ve enerjik olması yanı sıra pedagoji, spor, pazarlama, yönetim tecrübesi, gelişmiş iletişim becerisi ve birden fazla yabancı dil bilgisine de sahip olan bir kişi olarak bilinmektedir (Jakovlev, Koteski \& Bardarova, 2013; Medlik, 2003; Thibal, 1985). Bir animatörün dans, şark1 söyleme, resim yapma gibi konularda yetenekli olması işin kolaylaşmasını sağlar. Ayrıca kendi ülkesinin kültürünü en iyi şekilde temsil ettiği gibi turistlerin geldikleri ülkelerin kültürleri hakkında da bilgi sahibi olması oldukça önemlidir. Turistler arasında yaş, meslek, eğitim, kişilik özelliklerine bağlı olarak farklılıklar olduğunun bilincinde olma, animatörlere etkin iletişim kurmada önemli katkılar yaratabilmektedir (Ivkov ve Stamenkovic, 2008). Bu yetenekte ve bilinçte olmayan animatörlerin yaptıkları hatalar turistlerin tatilden duydukları memnuniyetleri olumsuz yönde etkileyerek bir daha aynı oteli tercih etmemelerine neden olabilmektedir (Demir, 2010). Yapılan araştırmalarda da animasyon hizmetlerinin turistlerin oteli tekrar tercih etmelerinde etkili olduğu sonucu ortaya konulmuştur (Costa, Glinia, Goudas \& Antoniou, 2004; Demir \& Demir, 2014a,b; Shportko, Lehto \& Ghiselli, 2013).

Turizmin bir hizmet sektörü olması, turist ile üreticinin aynı anda üretim ve sunum yerinde olmasını gerektirmektedir (Rowley, 1995). Doğal olarak bu durum çalışanlar ile tatil amaçlı konaklayanlar arasında yüksek oranda etkileşime neden olmaktadır (Güler, 2009; Vallaster ve Chernatony, 2005). Özellikle animasyon hizmeti direk turistle iletişimi gerektirdiğinden animatörler diğer çalışanlardan çok daha fazla müşteri-çalışan etkileşimi yaşamaktadır. Tüketicilerin animatörler ile yakın teması, onların olumlu veya olumsuz davranış ve performanslarının turistler tarafından anında değerlendirilmesinin (Tütüncü, 2009) yanı sıra işletme ile ilgili her türlü sorunlarını onlarla paylaşmalarına ve çözümleri onlardan beklemelerine neden olmaktadır. Animatörlerin turiste yönelik yaklaşımı, davranışları ve tutumu müşterilerin hizmetten memnuniyet duymalarını sağlayabileceği gibi sadakatlerini de sağlayabilmektedir. Yapılan araştırmalar, genel olarak çal1şanların müşteri memnuniyetinin dolayısıyla da sadakatinin sağlanmasında etken bir faktör olduğunu doğrulamaktadır (Demir \& Günaydın, 2013). Özellikle animasyon ekibinin diğer çalışanlara göre daha fazla müşterilerle iletişim halinde olması, daha samimi ilişkilerin kurulmasına olanak sağlamaktadır.

\section{Yöntem}

\subsection{Araştırmanın amacı}

Otel işletmelerinin animasyon hizmetlerine ilişkin alan yazında ve uygulamada farklı değerlendirmeler yer almaktadır. Buradan hareketle gerçekleştirilen bu araştırmanın amacı, otellerde sunulan animasyon hizmetlerinin yöneticiler ile turistler açısından değerlendirmesini yapmaktır. Bununla birlikte, her iki grupla yapılan görüşmelerden elde edilen bilgilerin karşılaştırılarak, animasyon hizmetlerinin otel işletmeleri için olduğu kadar turistler için de önemini ortaya koymaktır. 
Demir, M. \& Demir, Ş.Ş. (2015). The evaluation of hotel animation services from managers and tourists' perspective. International Journal of Social Sciences and Education Research, 1 (1), 35-48.

\subsection{Veri toplama}

Bu çalışmada nitel araştırma yöntemi seçilmiştir. Antalya ve Muğla Bölgesinde bulunan 4 ve 5 yıldızlı otellerde animasyon hizmetlerinden yararlanan turistlerle ve bu işletmelerin yöneticileri ile derinlemesine mülakatlar yapılarak gerçekleştirilmiştir. İşletme genel müdürlerinden randevu alınarak başlayan görüşmeler, bazı genel müdürlerin çeşitli nedenlerle görüşmeye katılmak istememesi nedeniyle yönlendirmiş oldukları diğer yöneticilerle gerçekleştirilmiştir. Katılımcılara önceden belirlenen yarı yapılandırılmış sorular yöneltilmiştir. Yarı-yapılandırılmış görüşme (mülakat), yapılandırılmış görüşmelerle yapılandırılmamış görüşmeler arasında kalan ve en çok kullanılan görüşme tekniğidir. Bu yöntem katılımcıların seçilen konulardaki genel ve teknik bilgi, düşünce, yorum, tutum ve davranışları kadar bunların neden ve sonuçlarının öğrenilmesinde en etkin yol olarak bilinmektedir.

$\mathrm{Bu}$ araştırmada nicel yöntem yerine nitel bir yöntem seçilmiştir. Çünkü araştırma hem turistlere hem de otel yöneticilerine yönelik yapılmaktadır ve her iki gruba da aynı ölçeği uygulamanın zorluğu nedeniyle derinlemesine mülakat yapılması tercih edilmiştir. İz sürme yöntemi kullanılarak 10 otel yöneticisi ve 22 turist olmak üzere toplam 32 katılımcıya ulaşılmıştır. Bu katılımcıların özellikleri tablo 1 ve tablo 2'de yer almaktadır. Her iki gruptan ilk katılımcı ile başlayarak yapılan görüşmeden sonra elde edilen bilgiler ışığında, bir diğerine geçilerek görüşmeler gerçekleştirilmiştir. Toplanan bilgilerin birbirini tekrar etmeye başlaması, araştırmada doyum noktasına ulaşıldığını göstermekte olup bu aşamadan sonra görüşmelere son verilmiştir. Katılımcıların her biri ile yaklaşık 20 dakika görüşülmüş olup toplam 10 soru yöneltilmiştir. Katılımcılardan alınan cevaplar, araştırmacıların analiz ve sentezleriyle deneyim ve mantık süzgecinden geçirildikten sonra alan yazındaki bilgilerle de bütünleştirilmiş ve yönetici ve turistlerin vermiş oldukları bazı cevaplar gruplandırılarak ortaya konulmuştur.

\subsection{Araștırma sinırlılıkları}

$\mathrm{Bu}$ araştırma, belirlenen birtakım sınırlılıklar içerisinde yapılmıştır. Öncelikle araştırma Antalya ve Muğla bölgesindeki 4 ve 5 yıldızlı otellerde gerçekleştirilmiştir. Otellerin seçiminde "animasyon ekibi ve kalitesi” bakımından çok büyük farklılıklar olacağı düşüncesi ile çok lüks zincir oteller yerine müşteri profili ve fiyat bakımından birbirine yakın olan oteller tercih edilmiştir. İkinci olarak, işletme genel müdürleri ya da müşterilerle daha yakın temasta olan departman yöneticileri ile görüşülmüsşür. Üçüncüsü görüşme yapmak için seçilen turistlerin daha öncede Türkiye'ye gelmiş ve birçok kez farklı otellerde animasyon hizmetlerinden yararlanmış kişiler olmasına dikkat edilmiştir.

\section{Bulgular}

Araştırmada yönetici ve turistlerden elde edilen veriler bir arada karşıllaştırılarak verilmiş ve birlikte değerlendirilmiştir. Veriler, hem otel yöneticileri hem de aynı otellerde tatil yapan müşterilerden elde edilmiştir. Yöneticiler tablo 1'den de anlaşılacağı gibi, genel müdür, önbüro müdürü, satış müdürü ve misafir ilişkileri müdürlerinden oluşurken, turistler Türk, İngiliz ve Almanlardan oluşmaktadır (tablo 2). Otel yöneticileri ve turistlerle yapılan görüşmelerde aynı soru formatı kullanılmıştır. Sorulara verilen cevaplarda, hizmeti sunan ile yararlananların algılamalarındaki farklı1ıkların yarattığı bakış açısı açıkça görülmektedir. Aynı şekilde yerli turistler ile yabancı turistlerin de farklı değerlendirmeleri olmuştur. 
Demir, M. \& Demir, Ş.Ş. (2015). Otel animasyon hizmetlerinin yöneticiler ve turistlerin bakış açısıyla değerlendirilmesi. International Journal of Social Sciences and Education Research, 1 (1), 35-48.

Tablo 1. Katılımcılar: Yöneticiler

\begin{tabular}{|l|l|c|l|}
\hline Katılımeı & Görevi & Otel sınıfı & Şehir \\
\hline GM-1 & Genel Müdür & $4^{*}$ & Bodrum \\
\hline GM-2 & Genel Müdür & $5^{*}$ & Alanya \\
\hline GM-3 & Genel Müdür & $5^{*}$ & Side \\
\hline GM-4 & Genel Müdür & $5^{*}$ & Alanya \\
\hline ÖM-1 & Önbüro Müdürü & $5^{*}$ & Bodrum \\
\hline ÖM-2 & Önbüro Müdürü & $4^{*}$ & Fethiye \\
\hline SM-1 & Satış Müdürü & $5^{*}$ & Bodrum \\
\hline SM-1 & Satış Müdürü & $5^{*}$ & Bodrum \\
\hline MiY-1 & Müşteri İlişkileri Yöneticisi & $4^{*}$ & Alanya \\
\hline MiY-2 & Müşteri İlişkileri Yöneticisi & $5^{*}$ & Marmaris \\
\hline
\end{tabular}

Bir otelde animasyon hizmetlerinin varlığı, hem müşteriler hem de yöneticiler açısından olumlu etki ve sonuçlar ortaya koyabilmektedir. Yöneticilerin satı̧ gücünü arttırabilme yönündeki çalışmalarına destek olarak görülebilecek animasyon hizmetleri, müşteriler açısından da bir otelin tercih edilmesine olumlu etki edebilmektedir. Nitekim animasyon hizmetlerinin bir otel için önemine ilişkin değerlendirmede, yöneticilerin tamamı "özellikle çocuklu aileler için önemli bir satış avantajı yarattığını" belirtirken, hem yerli hem de yabanc1 turistler, "otelde iyi bir animasyon hizmetinin olmasının otel tercihlerinde etkili olacağını" ifade etmektedir. SM-1'in "otele gelen bir misafir öncelikle animasyon olup olmadiğını soruyor" şeklinde ifadesini destekleyen bir başka görüşte GM-2'nin “müşteri otelde eğlence ister ve bu eğlence şeklide turistin milliyetine göre değişir" ifadesidir. Görülüyor ki, animasyon hizmetleri otel için önemli olduğu kadar müşteriler içinde önemlidir.

Tablo 2. Katılımcilar: Turistler

\begin{tabular}{|c|c|c|c|}
\hline Katılımcı & Milliyet & Cinsiyet & Tatil süresi (Gün) \\
\hline TR-1 & Türk & Erkek & 5 \\
\hline TR-2 & Türk & Kadın & 7 \\
\hline TR-3 & Türk & Kadın & 7 \\
\hline TR-4 & Türk & Kadın & 5 \\
\hline TR-5 & Türk & Erkek & 7 \\
\hline TR-6 & Türk & Erkek & 6 \\
\hline TR-7 & Türk & Kadın & 10 \\
\hline TR-8 & Türk & Kadın & 10 \\
\hline TR-9 & Türk & Erkek & 7 \\
\hline TR-10 & Türk & Kadın & 10 \\
\hline ALM-1 & Alman & Erkek & 14 \\
\hline ALM-2 & Alman & Erkek & 14 \\
\hline ALM-3 & Alman & Kadın & 7 \\
\hline ALM-4 & Alman & Kadın & 14 \\
\hline ALM-5 & Alman & Kadın & 7 \\
\hline ALM-6 & Alman & Kadın & 7 \\
\hline İNG-1 & İngiliz & Kadın & 7 \\
\hline İNG-2 & İngiliz & Erkek & 14 \\
\hline İNG-3 & İngiliz & Erkek & 14 \\
\hline İNG-4 & İngiliz & Erkek & 14 \\
\hline İNG-5 & İngiliz & Kadın & 14 \\
\hline İNG-6 & İngiliz & Kadın & 14 \\
\hline
\end{tabular}


Demir, M. \& Demir, Ş.Ş. (2015). The evaluation of hotel animation services from managers and tourists' perspective. International Journal of Social Sciences and Education Research, 1 (1), 35-48.

Animasyon departmanı otel için önemli işlevlere sahip bir birimdir. Yönetim ile müşteriler arasında bir köprü, otelin gülen yüzü, müşteriye en yakın otel personeli, hoş vakit geçirmenin kaynağıdır. Animasyon departmanının otel içinde aynı zamanda müşterilerin birbiriyle olan iletişimi ve ilişkisinin de sağlanmasında önemli bir rolü bulunmaktadır. Katılımcıların oteldeki animasyon departmanı ile ilgili düşüncelerinin ortak noktası "animatörler turistler arasındaki iletişimi, kaynaşmayı sağlar" ve "animasyon departmanı otel içinde önemli bir görev üstlenir" şeklinde hem yerli ve yabancı turistler hem de yöneticilerce aynı şekilde algılanmasıdır.

Otellerde animasyon departmanının verdiği hizmetler gece ve gündüz farklılık göstermektedir. Gündüz daha çok yarışmalar ve spor etkinlikleri olurken gece ağırlıklı olarak skeçler, dans gösterileri, müzikaller ve playbacklerden oluşan bir program turistlere sunulmaktadır. Ancak çoğu kez özgünlükten uzak, yıllardır tekrar eden gösteri ve yarışmalar turistlere sunulmaktadır. Animasyon departmanının sunmuş olduğu programların otellere göre farklılık gösterip göstermediğinin belirlenmesi amacıyla hem yöneticiler hem de turistlere aynı soru yöneltilmiştir. Yöneticilerin ve katılımcıların hali hazırda bulundukları otelden başka tesis deneyimine sahip olması, karşılaştırma yapabilmesi açısından önemlidir. Çalışmaya katılan turistlerin büyük çoğunluğu (\% 82) otel animasyon programlarının özgün olduğunu belirtmişlerdir. Yabancı turistlerin ilk kez Türkiye'ye gelmiş olmaları (Türkiye dışında başka ülkelerdeki otel animasyon programlarını seyretmişlerdir) ve Türk turistlerin de otelde ilk kez farklı amaçla (bir kısmı çocukları nedeniyle ilk kez çocuk animasyonlarına katılmışlar, bir kısmı da çocuklarının büyümesi nedeniyle yetişkin programlarına katılmışlardır) animasyon programlarına katılmalarından kaynaklanabilir. Türkiye'ye üç y1ldır geldiklerini belirten ALM-1, ALM-2 ve İNG-3 "diğer otellerde geçen yıllarda izlediğim skeçlerin biraz daha farklılaştırılmış haliydi" diyerek gösterilerin yenilenmediğine dikkat çekmektedir. İNG-5 "daha önceki yillarda Türkiye'de bulunduğumuzdan gece gösterilerini daha önce bir kaç kez izlemiştik bu nedenle gece gösterilerine pek fazla katılmuyoruz” ALM-3 "gündüz tanıtımlarda özgün bir gösterinin olacăğ bilgisini alırsak o zaman gösteriyi izlemeye gidiyoruz" şeklinde görüşlerini bildirmiştir.

Yöneticilerin tamamı animasyon hizmetlerinin lüks oteller dışında birbirinin aynı olduğunu ifade etmişlerdir. SM-2 "Otelimizde sıradan bilinen programların yanında özgün yenilikçi programlarda yer almaktadır. Siradan bilinen programlarla başarılı olma şansınız çok azdır. Ne kadar yenilik o kadar memnuniyet söz konusudur" şeklinde yeni programların olmasının gerekliliğini vurgulamıştır. GM-3 ise, "özgün gösteriler (revü showları, özel müzikaller, ünlü sanatçılar gibi) çok yüksek maliyetlidir ve her otelin bu maliyeti karşılaması mümkün değildir. Ancak büyük ve lüks oteller bu maliyeti karşılayabilir" diyerek konunun bir başka boyutuna dikkat çekmiştir. Turistlerin yöneticilere göre gösterilerin daha özgün olduğunu düşünmelerinde geçmiş yıllardaki deneyimlerinin azlığı önemli bir rol oynamaktadır. Yöneticiler yıllardır bu sektörün içinde olduklarından hangi otelin nasıl bir animasyon hizmeti verdiği konusunda daha deneyimlidir.

Tüketicinin bir ürün veya hizmetten beklentisi geçmiş yıllardaki deneyimlerinden, tanıdıkları ve arkadaşlarının anlattıklarından, işletmelerin reklam ve tanıtımlarında vaat ettikleri hizmetlerden oluşmaktadır. Turistlere; otel animasyon hizmeti beklentilerinizi karşıladı mı? sorusuna turistlerin büyük çoğunluğunun (\%77) animasyon hizmetlerinin beklentilerini karşıladığını ifade ederken yalnızca 5 kişi (\%23) animasyonların genelde oteldeki müşterilerin çoğunlukta olduğu millete göre hazırlandığını ifade etmiştir. Buna karşın, aynı soru, bir başka bakış açısıyla, yöneticilere animasyon hizmetinizin müşteri beklentilerini karşıladığını düşünüyor musunuz? şeklinde 
Demir, M. \& Demir, Ş.Ş. (2015). Otel animasyon hizmetlerinin yöneticiler ve turistlerin bakış açısıyla değerlendirilmesi. International Journal of Social Sciences and Education Research, 1 (1), 35-48.

yöneltilmiş̧ir. Görüşmeye katılan yöneticilerin yarısı animasyon hizmetlerinin turistlerin beklentilerini karşıladığ1, yarısı da karşılamadığı görüşündedir. SM-2 "animasyon program açısından \%70 oranında turistlerin beklentilerini karşılamaktadır, ancak turistle animatörün karşıllklı diyaloglarında \%100 oranında turistlerin beklentileri karşılanmaktadır", ÖBM-1 ise "beklentilerin karşılanması animatöre bağlıdır, animatör mesleğinde iyi ise müşteri beklentileri karşılanır" şeklindeki yorumlar aslında gösterilerden daha önemlisinin animatörlerin müşterilere karşı ilgisi ve iletişim becerileri olduğunu göstermektedir. Bu ifadelerden anlaşıldığı üzere otellerde kalifiye animatör istihdam edilmesi animasyon hizmetlerinin başarısında oldukça önemli bir rol oynamaktadir.

Bir otelden memnun ayrılan turist iki tür davranış göstermektedir. Bunlardan birincisi, bir sonraki tatil için yine aynı otele gelmek, ikincisi ise kendisi gelmese bile arkadaş ve tanıdıklarına oteli tavsiye etmektir. Otellerin sadık müşterilerinin fazla olması, karlılığı arttırmada, risklerle karşılamada, diğer otellerle rekabette oldukça avantajlı olmalarını sağlar. Turistlere animasyon hizmetlerinden dolayı tekrar bu otele gelir misiniz? diye sorulduğunda yerli turistlerin ikisi (TR3 ve TR-5) dışındaki büyük çoğunluğu "evet tekrar gelmek isterim" diye cevaplandırırken, yabancı turistler otel tercihinde animasyon hizmetlerini doğrudan önemli bir etken olarak görmeyerek büyük çoğunluk "hayır, animasyon için bir daha aynı otele gelmem" demişlerdir. Aynı soru yöneticilere müsterilerinizin otelinizi yeniden tercih etmelerinde animasyon programları etkili olur mu? ifadesi ile sorulmuş bir yönetici dışındaki diğer yöneticilerin ortak görüşü "eğer turist otelin animasyon hizmetinden memnun kalmışsa bu onların tekrar işletmeyi tercih etmesinde diğer unsurlar ile birlikte etkili olacaktır" şeklindedir. GM-3 "tahminen \% 30 oranında etkili olur. Kimi turiste göre animasyon hizmeti otelin olmazsa olmazıdır, kimine göre ise olsa da olur olmasa da olur" şeklinde aşırı bir etkisinin olmayacağ yönünde görüş bildirmiştir.

Animasyon hizmeti turistlerin oteldeki eğlence arayışlarından doğmuştur. Gündüz saatlerini deniz veya havuzda geçiren turist için akşam saatlerinde yapacak çok fazla alternatif yoktur. Özellikle tatilleri boyunca çok fazla otel dışına çıkmayan turistler her tür eğlenceyi de otelden beklemektedir. Animasyon hizmeti olmazsa otel sikıcı olur mu? sorusuna yerli turistlerin tamamı kesinlikle sıkıcı olur şeklinde cevap verirken, yabancı turistlerin bir kısmı sıkıcı olmayacağını, bir kısmı ise kesinlikle sıkıcı olacağını belirtmiştir. Özellikle bu tür gösterileri gürültü olarak gören ve tatilinde sakinlik arayan turistler için animasyon hizmetinin olmaması daha iyidir. Nitekim INNG-6 "keşke hiç animasyon hizmeti olmasa da gürültü azalsa" diyerek animasyon hizmetini gereksiz bir hizmet olarak görmektedir. TR-4 ise, "gündüz yarışmalarına katılmaktan büyük zevk alıyorum. Özellikle yabancılarla rekabet edeceğimiz yarışmaları daha çok seviyorum. Ĕger animasyon hizmeti olmasa bütün gün havuza ve denize girmekten çok sıkllırdım" diyerek animasyon hizmetinin gerekliliğine işaret etmiştir. Aynı soru yöneticilere sorulduğunda genel olarak bütün yöneticiler animasyon olmazsa turistin otelde sıkılabileceğini belirtmiştir. SM-1 "otellerin birçoğunda relax diye tabir ettiğimiz klsımlar bulunur plaj ve relax havuz gibi zaten animasyon istemeyen misafirlerimiz oradan faydalanarak tatillerini geçirirler. Diğer misafirlerimiz içinse animasyon olmazsa olmazlardandır" şeklinde yorumda bulunmuştur. GM-1 ise, "turistler akşam d $l^{-}$ şarı çıkmadıkları için otel içinde eğlence istemektedir. Animasyon hizmeti olmazsa misafirlerimiz slkılabilir" diyerek animasyon hizmetinin bir otelde iyi veya kötü mutlaka bulunması gerektiği vurgulanmıştır. 
Demir, M. \& Demir, Ş.Ş. (2015). The evaluation of hotel animation services from managers and tourists' perspective. International Journal of Social Sciences and Education Research, 1 (1), 35-48.

Bir oteldeki animasyon hizmetleri genel olarak gündüz programı, gece gösterileri ve mini kulüpten oluşmaktadır. Animasyon programlarının çeşitliliği (mini kulüp, su sporları, gece ve gündüz showlart) otel tercihinizde etkili oldu mu? şeklindeki bir soruya ALM-6 "otele gelmeden önce sadece animasyon hizmetinin olup olmadı̆̆ın sorduk, ancak ne tür animasyon hizmeti verileceği ile ilgili ayrıntılı bilgi almadık, daha çok diğer faktörler (otelin yeri, ylldızı, pansiyon türü gibi) otel tercihimizde etkili oluştur". ALM-5 "çocuğumuz olduğu için sadece mini kulübün olup olmadiğını sorduk" diye belirtmiştir. Otel yöneticileri arasında animasyon hizmetlerinin çeşitliliğinin kesinlikle turistlerin otel tercihinde etkisi olacağını özellikle çocuklu aileler için mini kulübün olmasının önemli olduğunu belirtenlerde olmuştur. "Otel tercihlerinde animasyon hizmetleri etkili olur ama lokasyon kadar değil" diyen ya da "ne yazık ki genel anlamda misafirlerimiz animasyon için değil de herşey dahil olsunda ne olursa olsun düşüncesi ile otel tercihlerini yapıyor. Bunun yanında animasyonun olması tatllsı şerbeti oluyor" diye görüş bildirenlerin de olması turistlerin tatil tercihlerinde farklı faktörlerin etkili olduğunu göstermektedir.

Otelde animasyon hizmeti hiç olmaması sizi nasıl etkiler? sorusuna, görüşmeye katılan hem yerli hem de yabancı turistler şaşırtıcı bir şekilde otelde animasyon hizmeti olmasa da önemli olmadığını belirtmişlerdir. Diğer sorulara verilen cevaplarla çelişkili gibi görünen bu cevap aslında turistlerin iyi bir animasyon hizmeti istediklerini, eğer böyle olmayacaksa animasyon hizmeti olmasa da onlar için bunun çokta bir öneminin olmadığı anlamı çıkmaktadır. Yöneticilere aynı soru oteli, acentayı ve müşterileri etkilemesi bakımından sorulmuştur. ÖBM-2 "animasyon otelde farklı kültür ve milletlerden konaklayan misafirlerin kaynaşması, birbirlerini daha yakından tanıması ve iyi zaman geçirmelerini ayrıca otel yönetimi ile misafirler arasında bir köprü oluşturmaktadır. Animasyon ekibinin olmaması bu köprü ve ilişkilerin sağlanamaması dolaylstyla otel yönetiminin misafir istek ve ihtiyaçlarının sadece resepsiyon ve halkla ilişkiler departmanlarından alacă̆ bilgiler doğrultusunda hareket edeceği bunun sonucunda misafirlerin tam anlamıyla istek ve ihtiyaçlarına karşılık verememesine neden olacaktır. Halkla ilişkiler ve resepsiyon misafir ile formal iletişim kurmaktadır. Animasyon departmant ise hem formal hem de informal bir iletişim içerisindedir. Misafirler kendi istek ve ihtiyaçlarını bu departmana daha samimi bir şekilde ifade etmektedir. Animasyon departmanının olması konaklayan misafirlere tam anlamıyla ulaşılmasını hedefleyen işletmelerin olmazsa olmazıdır" şeklinde otel için animasyon hizmetinin olmasının önemini açıklamıştır. SM-1'de "bölgedeki otellerde olması animasyon hizmeti olmayan oteli satış ve kalite yönünden etkiler" şeklinde cevaplandırmıştır.

Görüşmeye katılan turistlere, animasyon hizmetlerinden rahatsızlık duyduğunuz yönleri nelerdir? diye sorulduğunda, istisnasız tüm katılımcılar animatörlerin etkinliklere katılım konusundaki ısrarlarından rahatsız olduklarını belirtmişlerdir. Ayrıca Türk müşteriler gece gösterilerinin müstehcen olmasını bu nedenle çocuklarına izletmek istemediklerinden dolayı rahatsızlıklarını bildirmiştir. TR-9 "animasyonun gece gösterileri kısmına çocuklar mini discoya katılsinlar diye gidiyoruz. Skeçler başladı̆̆ında oldukça müstehcen olduğu için hemen odamıza dönüyoruz. Çocuklar ısrarla kalmak istiyorlar ama biz seyretmelerini uygun bulmuyoruz. Keşke insanları güldürmek ve e ğlendirmek için belden aşağı espri yapılması gerekmese daha farkll yollarla da insanlar e $\breve{g}$ lendirilebilir" diyerek animasyonun bu kadar kısır bir eğlence şekli olmaması gerektiğine vurgu yapmaktadır. TR-7 "bizim kültürümüzde yer almayan bazı gösterilerin sanki bize aitmiş gibi gösterilmesinden rahatsılık duydum" diyerek Türk kültürüne özgü gibi gösterilen, ancak Arap ve Afrika kültürüne ait bazı gösterilerin yapılmasının Türk müşterileri rahatsız ettiğine işaret etmek- 
Demir, M. \& Demir, Ş.Ş. (2015). Otel animasyon hizmetlerinin yöneticiler ve turistlerin bakış açısıyla değerlendirilmesi. International Journal of Social Sciences and Education Research, 1 (1), 35-48.

tedir. Yabancı turistler ise daha çok gece gösterilerinin ve sahne dekorunun basitliğinden rahatsızlık duyduklarını belirtmişlerdir. Özellikle daha önce daha lüks otellerde animasyon gösterisi izlemiş olan bazı turistler animatörlerin gidip o otellerdeki gösterileri izlemelerini önermişlerdir.

\section{Sonuç ve tartışma}

Araştırmada otel animasyon hizmetlerinin birbirine benzer olduğu ve genellikle aynı hizmetleri kapsadığı görülmektedir. Gündüz her otelde yapılan yarışmalar, spor faaliyetleri ve diğer etkinlikler hemen hemen aynıdır. Gece gösterileri de genellikle basit kostüm ve sahne dekoru ile hazırlanmış bilinen skeçlerin tekrarı şeklindedir. Bunda tur operatörlerini paket turlarla birlikte getirdikleri daha çok Tunuslu ve Faslı olan ilk animatörlerin etkisi çok fazla olmuştur. Bu animatörlerin yetiştirdiği bu günkü animatör şefleri o zaman öğrendikleri ve yaptıkları gösterilerin üzerine pek fazla yenilik katamamışlardır. Türk geceleri kapsamında yapılan gösteriler dışında ülke kültürünü yansıtmamaktadır. Arap-Hint kültürüne özgü Fakir show veya Afrikalı dansçıların yaptığı gösterilerin Türk kültürüne özgü eğlenceler gibi turistlere sunulduğu görülmektedir. Özellikle herşey dahil sistemi uygulayan otellerden hiç çıkmayan ve yerel halkla hiç temasa geçmemiş olan turistler ülke kültürünü hiç tanımadan ülkeden ayrılmak zorunda kalmaktadır. Oysaki o ülke kültürünü yansıtan animasyon gösterileri ile turist sadece yerel ortama aşina olmakla kalmaz, hem de aktif olarak sürecin içinde yer alır ve animatörlerin yardımıyla ziyaret edilen ülke ile ilgili kendi deneyimlerini yaratabilirler.

Araştırmada animasyon hizmetlerinin bir otelde olmasının en önemli yararlarının müşterilerin birbirleri ile daha iyi iletişim kurabilmelerinin sağlanması yanında müşterilerin işletme ile ilgili şikayet veya isteklerini animatörlere çok daha kolaylıkla iletebilmeleridir. Turistlere doğru yaklaşan ve onlarla iyi diyaloglar kurabilen tecrübeli animatörler sayesinde işletmedeki bazı aksaklıklar müşteriler tarafından hoş görülebilecek ya da daha kolay bir şekilde müşteri şikayetleri giderilebilecektir. Bu durum turistlerin otel memnuniyetlerine yansıyarak tekrar işletmeyi tercih etmelerine ya da arkadaşlarına ve tanıdıklarına işletmeyi önermelerine neden olabilecektir. Ancak animatörlerin özelliklede bu işe yeni başlamış olanların, turistleri rahatsız edici yaklaşımları, onları etkinliklere katılmaya zorlamaları, müşteri memnuniyetinin azalmasına neden olabilmektedir.

Diğer bir sonuç otellerin animasyon departmanlarına yeteri kadar önem vermediklerini göstermektedir. Bu departmanı diğer departmanlardan farklı görmemekte, otelde mutlaka olması gerektiğini düşünmekte ancak verilen hizmetin kalitesine çok da önem vermemektedir. Otel yönetici ve sahipleri için önemli olan maliyetlerin ne kadar düşürülebildiğidir. Bu nedenle animasyon departmanı için yeterli bütçe ayrılmamaktadır. Animatöre çok yüksek maaşlar ödememek için bu işin inceliklerini bilmeyen acemi personel veya stajyerlerle günü kurtarmaya çalışmaktadır. Sahne dekoru, kostüm, spor malzemesi gibi animasyon departmanının kullandığı ekipmanlara da çok para harcanmasını istememektedir. Ancak unutulmamalıdır ki personel ve malzeme yeterli olmazsa en iyi animatör şefinin bile müşteri memnuniyetini sağlamak için yapabileceği bir şey kalmamaktadır. Müşteri istek ve beklentilerinin karşılanmasında, şikayetlerin değerlendirilmesinde ve otel-müşteri ilişkilerinin kurulmasında animasyon departmanı önemi oldukça fazladır. Otel işletmelerinin Türk kültürünü yansıtabilecek özgün gösterilere yönelik çalışmaların yapılması, kalifiye animatörlerin istihdamı ve yetiştirilmesi, kaliteli hizmet sunumu ve memnun müşteri yaratılması için animasyon hizmetlerine ekip, araç-gereç malzeme, program, nitelik ve niceliksel olarak önem vermeleri gerekmektedir. 
Demir, M. \& Demir, Ş.Ş. (2015). The evaluation of hotel animation services from managers and tourists' perspective. International Journal of Social Sciences and Education Research, 1 (1), 35-48.

\section{Kaynakça}

Borhan, O. \& Erkmen, N. (2010). Antalya'nın Kemer ilçesinde tatil yapan turistlerin rekreasyon ve animasyon faaliyetleri hakkındaki görüşlerinin incelenmesi. Turkish Journal of Sport and Exercise, 11(3), 21-26.

Costa, G., \& Glinia, E. (2004). Sport tourism in Greece. Journal of Sport \& Tourism, 9(3), 283-286.

Costa, G., Glinia, E., Goudas, M. \& Antoniou, P. (2004). Recreational services in resort hotels: Customer satisfaction aspects. Journal of Sport \& Tourism, 9(2), 117-126.

Demir, M. \& Demir, Ş.Ş. (2001). Herşey Dahil (All Inclusive) Pansiyon Türü Uygulamasının Konaklama İşletmeleri, Personel, Müşteriler, Seyahat Acentaları ve Bölgedeki Diğer İşletmeler Açısından Olumlu ve Olumsuz Yönlerinin Analizi. Maltepe Üniversitesi Turizm Araştırmaları Dergisi, 1 (1), 67-100.

Demir, Ş.Ş. \& Günaydın, Y. (2013). İşgörenlerin müşteri sadakati üzerindeki etkileri: Konaklama işletmeleri örneği. The Journal of Academic Social Science Studies, 6(6), 1039-1059.

Demir, Ş.Ş. (2010). Tatil satınalma sürecinde itici faktörler, bilgi arama ve memnuniyet ilişkisi: Yerli turistler üzerine bir araştırma. İşletme ve Ekonomi Araştırmaları Dergisi, 1 (4), 119-132.

Demir, Ş.Ş. \& Demir, M. (2014). Kamu Kesimindeki Yöneticilerin Serbest Zaman Etkinliklerini Algılaması ve Değerlendirmesi. Manas Sosyal Araştırmalar Dergisi 3 (11), 61-76

Demir, Ş.Ş. \& Demir, M. (2014). İşgörenlerin Serbest Zaman Gereksinimi ve Serbest Zaman Doyumunu Etkileyen Faktörler. İşletme ve İktisat Çalışmaları Dergisi 2 (3), 74-84

Glinia, E., Costa, G. \& Drakou, A. (2004). Hotel animation and professional perspectives in Greece. Tourism Today Tourism Today. www.cothm.ac.cy

Güler, E.G. (2009). Otel işletmelerinde değer yaratma ve müşteri değeri algılaması üzerine bir araştırma: Edirne'deki oteller örneği. Anatolia: Turizm Araştırmaları Dergisi, 20 (1), 61-76.

Hornby, P. ve Symon, G (1994). “Tracer studies”, (Eds: C. Casselland G. Symon). Qualitative methods in Organisational Research: A Practical Guide. 167-186, London: Sage,

Ivkov, A., \& Stamenkovic, I. (2008). The implementation of the "Bologna Process" into the subject of animation in tourism, as a significant part of the hotel industry products promotion. Tourism \& Hospitality Management, 14 (1), 129-140.

Jakovlev, Z., Koteski, C., \& Bardarova, S. (2013). Animator roles in enriching the content of tourist stay. In Collection of works of The Third International Scientific Congress-Biennale ICON BEST 2013.

Karasar, N. (2002). Bilimsel Araştırma Yöntemi. Ankara: Nobel Yayınları.

Koçak, N. (2001). Konaklama işletmelerinde animasyonun önemi ve animasyon personeline yönelik bir araştırma. Dokuz Eylül Üniversitesi İktisadi ve İdari Bilimler Fakültesi Dergisi, 16(1), 61-79.

Luborsky, M. R. (1994). Qualitative Research in Ageing Research. Thousand Oaks: Sage.

Medlik, S. (2003). Dictionary of travel, tourism and hospitality. Routledge.

Mikulić, J. \& Prebežac, D. (2011). Evaluating hotel animation programs at Mediterranean sun-and-sea resorts: An impact-asymmetry analysis. Tourism Management, 32(3), 688-696.

Pompl, W. (1983). The concept of animation: Aspects of tourism services. Tourism Management, 4(1), 311.

Rowley, J.E. (1995). From storekeeper to salesman: Implementing the marketing concept in libraries. Library Review, 44 (1), 24-35. 
Demir, M. \& Demir, Ş.Ş. (2015). Otel animasyon hizmetlerinin yöneticiler ve turistlerin bakış açısıyla değerlendirilmesi. International Journal of Social Sciences and Education Research, 1 (1), 35-48.

Shportko, A. (2012). The Effect of Animation Services on the Guests' Perception of a Hotel and Intention to Visit it (Doctoral dissertation, Purdue University).

Shportko, A., Lehto, X., \& Ghiselli, R. (2013). Investigating guest experience and satisfaction with hotel animation. In The 18 th Annual Graduate Education and Graduate Student Research Conference in Hospitality and Tourism.

Thibal, S. (1985). A changing career in tourism. Espaces, (75), 31-34.

Tütüncü, Ö. (2009). A ̆ğırlama Hizmetlerinde Kalite Sistemleri. Ankara: Detay Yayınevi.

Vallaster, C. \& De Chernatony, L. (2005). Internationalisation of service brands: The role of leadership during internal brand building process. Journal of Marketing Management, 13, 181-203.

Vogt, C. A., \& Fesenmaier, D. R. (1995). Tourists and retailers' perceptions of services. Annals of Tourism Research, 22(4), 763-780. 
Demir, M. \& Demir, Ş.Ş. (2015). The evaluation of hotel animation services from managers and tourists' perspective. International Journal of Social Sciences and Education Research, 1 (1), 35-48.

\section{Extended abstract in English}

Animations at resort hotels include mini club, sports, evening entertainment/shows and entertainment programs as different indoor and outdoor activities. This study evaluates the hotel animation activities from both managers and tourist perspective.

Purpose and Significance: In tourism industry, hotel animation programs and activities are a generally used term to describe entertainment and recreational services offered by resorts facilities in tourist destinations. Because animation services include three types of animation programs such as, sports activities, evening entertainment/shows and entertainment programs for children. And animation term also includes dance, shows, mini club activities, sports activities in swimming pool and/or outdoor for tourists who desire active recreation, have fun and social interaction with each other. It stated that hotel animations are important for both management and tourists. Tourist satisfaction with recreational and animation services can contribute to increase food and beverage sales during show programs at hotels and resorts in the coastal regions. The resort hotels offer different animation shows and programs as services free of charge, aiming at high sales of food and beverages which increase their profits. This paper reviews the nature of animation services. Therefore, the purpose of this study is to evaluate hotel animation services from managers and tourist perspective.

Literature: One of the attributes and attractiveness is animation activities which hotel present. It is stated that indoor and outdoor animation activities is a great opportunity to improve marketing public relations. Tourists have a better opinion of hotels which stayed with animation activities and they come back again in the future. It is explained that lots of reasons to be important at a hotel; a) the effects on a positive image of the hotel, b) can provide to increase repeat guest to the hotel in the future, c) cause to increase consumption in the restaurant, bar, swimming pool and increase total profit of the hotel, d) take care of children, allowing parents to relax and e) other positive impacts both tourist and hotel management.

In effective animation shows, the ability, performance, communication skills and cultural knowledge of animators are important and have crucial role on tourists' expectations. Nevertheless, there have been contradictory findings regarding the qualification of animators and the variety of animation activities at resort hotels. According to tourists, the quality and variety of animation activities are not sufficient level. Although the animation activities at hotels are important, hotel managers do not allocate higher budget for animation team, equipment and other requirements. Due to cheaper, animation activities include only Indian, Arabic, Russian or African shows and are presented by foreign animators as Turkish culture.

Methodology: This paper which qualitative research method was used in, firstly, a literature review that related to recreational and animation services at hotels were conducted and then data were collected by researchers in face-to-face interviews with 10 managers (4-General Manager, 2-Front Office Manager, 2-Sales and Marketing Manager and 2-Customer Relation Manager) and 22 tourists (10-Turkish, 6-German and 6-English) at five stars hotels and resorts in Antalya region (Alanya, Kemer and Manavgat) and Muğla region (Fethiye, Marmaris, Bodrum and Dalaman).

Results and Conclusion: The results indicate that managers and tourists believe in hotel animation programs and people have a crucial role on customer satisfaction. Animation activities provide the most satisfaction for the family with children. Because children's expectation and desire differs from their family and the "variety of activities" in animation is the most influential 
Demir, M. \& Demir, Ş.Ş. (2015). Otel animasyon hizmetlerinin yöneticiler ve turistlerin bakış açısıyla değerlendirilmesi. International Journal of Social Sciences and Education Research, 1 (1), 35-48.

attribute in explaining satisfaction of their holiday. The findings of the evaluation of hotel managers about animation activities have a positive and significant effect on tourists' holiday satisfaction which creating their loyalty. Hotel managers stated that tourists purchase different good and services at hotel if they stay longer and spend more time in facilities. Both hotel managers and tourists agreed that the animation activities facilitate the sales efforts of hotel services.

This study explored the evaluation of animation activities at resort hotels from managers and tourists' perspective. Hotel animation activities is the tool that can provide managers to increase the sale of hotel gadgets and services in facilities and satisfy tourists' needs for social interaction, relaxation and having a good time during holiday. This study presented that tourists' evaluation of hotel animation activities are different from managers' evaluation. The quality of animation programs and animators can affect both hotel goals and tourist expectations. Animators who plays with kids, organizes sports activities and presents evening shows for tourists are on a critical position at the hotel. 